\title{
Strategies and implications for network participation in regional climate and energy planning
}

Jenny Palm and Josefin Thoresson

\section{Linköping University Post Print}

\section{Tweet}

N.B.: When citing this work, cite the original article.

This is an electronic version of an article published in:

Jenny Palm and Josefin Thoresson, Strategies and implications for network participation in regional climate and energy planning, 2014, Journal of Environmental Policy and Planning, (16), 1, 3-19.

Journal of Environmental Policy and Planning is available online at informaworldTM: http://dx.doi.org/10.1080/1523908X.2013.807212

Copyright: Taylor \& Francis (Routledge): STM, Behavioural Science and Public Health Titles / Wiley: No OnlineOpen

http://eu.wiley.com/WileyCDA/Brand/id-35.html

Postprint available at: Linköping University Electronic Press

http://urn.kb.se/resolve?urn=urn:nbn:se:liu:diva-105154 


\section{Introduction}

Rapid environmental degradation and natural resource consumption are growing global concerns, leading to awareness that ecological sustainability is a critical new planning goal. Regions and municipalities need to take initiatives to improve their energy efficiency, protect their natural resources, and improve their environmental sustainability. Both these administrative levels need to play key roles in implementing national energy and environmental strategies and in formulating their own strategies. Local and regional authorities often also become key actors in areas such as energy planning, energy advisory activities, Agenda 21 activities, and fighting climate change (see e.g., Palm, 2006; Aall et al., 2007; Baker \& Eckerberg, 2007; Betsill \& Bulkeley, 2007; Burch, 2010; Narodoslawsky \& Stoeglehner, 2010). It is in the regions and municipalities that ambitious national and international policies and goals are put into practice.

In Sweden, the local, municipal level has traditionally occupied a strong position, having considerable autonomy and power. In contrast, the regional administrative level, represented by County Administrative Boards (CABs), has been weak, possessing vague responsibilities. CABs occupy a precarious position, poised between the local and national administrative levels. The importance of the regional level in regional planning, however, has started to increase, and in the 2008 budget document (Swedish Government, 2008), the national government assigned the CABs the task of developing regional climate and energy strategies for each region. This assignment calls on CABs to take responsibility for creating regional climate and energy strategies in order to develop sustainable energy systems and reduce climate mitigation in the counties. Coordinating and involving other stakeholders to implement the strategy work is essential to the strategy assignment (Palm, 2011). 
Participation has been institutionalized in urban planning since the 1990s. From a democratic perspective, most researchers agree on the benefits of participation when it comes to the values embodied in the outcomes in practice, but doubts have been raised regarding the efficiency of participatory planning (Monno \& Khakee, 2012). Participation has been treated as a waste of time, and the weak link between participatory input and outcome has also been criticized (for a more thorough discussion, see Monno \& Khakee, 2012). The crisis in participation has been explained in relation to institutional flaws, a focus on consensus building, and the nature of energy planning in particular. Kowalski et al. (2009) believes that the need for technical knowledge hinders stakeholder participation throughout the energy planning process. On the other hand, public participation is often not seen as a choice but a necessity, making it important to consider the decision-making questions and purpose when deciding what stakeholders to include (Tonn et al., 2000; Buono et al., 2012).

In developing sustainable energy systems, the CABs have been commissioned a metagovernor role. A meta-governor is an actor responsible and accountable for a project and plays a coordinating role in the network. The CABs have been commissioned to establish strategic planning initiatives at the regional level and are responsible for promoting the issue: they should not do everything on their own, but work in cooperation with other actors. This article will contribute to the participation debate by discussing how the planners', in this case the Swedish CABs, more or less unintentional participation approach has influenced the range of goals implemented. We will compare four CABs in Sweden that provide fairly different examples of how to approach stakeholder participation in regional climate and energy planning. All four cases highlight the problems arising when authorities are required to 
involve stakeholders in the planning process, but do so without reflecting on the needs or benefits of participation.

Our aim is to analyze how CABs have used various participation approaches when establishing networks, in order to examine how these strategies have influenced the implementation of regional climate and energy strategies and, consequently, the realization of their goals. Do different participation approaches have different implications for acceptance and implementation of the strategies?

\section{Regional Energy Planning in Sweden}

The Swedish planning system is decentralized. The municipalities are strongly self-governing, retaining taxation rights and a monopoly on planning, with only a few exceptions. Local selfgovernment has a long tradition in Sweden, and the municipalities have the power to decide where, when, and how the built environment should develop. In 1987, the new Plan and Building act (PBA) strengthened the municipalities' planning monopoly, since much governmental control was removed. The municipalities continued to retain considerable control, at least in relation to the governmental and regional levels (Magnusson, 2011). The long history and entrenchment of local government has resulted in a weak regional level. In addition, Sweden has not established a single form of regional organization, but various experiments have led to a piecemeal system with differences between the administrative regions (Westholm et al., 2008).

Municipal energy planning in Sweden is governed by the PBA of 1997 and the Law on Municipal Energy Planning (LMEP) (SFS 1977:439). According to the PBA, stakeholder 
participation is required in order to improve the basis of decisions, create transparency in the decision process, and allow stakeholders to influence decisions. LMEP urges collaboration between municipalities, large stakeholders (e.g. industries) and companies producing energy (SFS 1977:439).

The CABs have previously dealt with environmental issues, for example, regarding the supervision and monitoring of national environmental goals. However climate and energy planning at the regional administrative level did not start until 2008, when the CABs were tasked with developing regional climate and energy strategies in order to develop sustainable energy systems and reduce climate change (Swedish Government, 2008).

CAB's tasks and mandate have traditionally been focused on central government coordination, supervision, permits and other legal applications, follow-up, evaluation, and cross-sectoral knowledge creation. The CAB role and tasks were however debated in 2003 to 2008 by the Committee on Public Sector Responsibilities (Ansvarskommittén) commissioned to analyse the current system of public administration, the division of responsibilities and in structural arrangements in order to meet the challenges public sector services will face in the future (SOU 2007:13).

The Committee on Public Sector Responsibilities wanted regional development mandate to be assigned to the newly established regional authorities. The CAB's role would be focused on supervision, permits and other legal application. The Committee's proposals were, however, not realized, but it had consequences. Local and regional actors started to questions the CABs role and mandate, and not least in relation to developing regional energy and climate strategies. 
During this time period, several public actors in the regional arena wanted to take responsibility for regional energy issues. These include the Regional Cooperation Council, organized by the municipalities in a county, which wants to assume overall responsibility for regional development. In addition, some regions have acquired a Regional Energy Agency with a regional focus on energy issues. Local officials and politicians also want to keep their power of self-government on these issues. They all want to be the regional actor pursuing regional sustainable energy systems.

\section{CABs as Meta-governors of the Planning Process}

However, it is the CABs that have been commissioned to develop regional climate and energy strategies. A regional strategy functions by articulating an orientation shared by many stakeholders in a regional development process. Because strategies are social products formed in networks within governance structures, questions concerning legitimacy and accountability are vital when working with strategies that influence the direction of regional energy systems (Albrechts, 2004; Healey, 2009).

According to governmental budget documents directed toward the CABs, regional sustainable energy systems are to be developed by creating arenas and processes in which regional actors can meet and develop common strategies. Such processes are often collectively labeled governance. Theories of governance often draw attention to how and why actors that are not part of the political sphere participate in forming politics in the broad sense, and to how new arenas and coordination forms are created and used (Sabatier \& Jenkins-Smith, 1993; Pierre, 2000). 
In the process of developing climate and energy strategies, the CABs have been commissioned to act as meta-governors. Governance theorists use the term 'metagovernance', defined as the regulation of self-regulation (Jessop, 2003; Sørensen, 2006), to describe how public authorities relate to self-governing networks. Metagovernance deviates from traditional rule-based forms of governing in that it seeks to maintain the self-governing capacity of networks.

From a metagovernance perspective, the assumption is that one actor, the meta-governor, is responsible and accountable for a project and plays a coordinating role in the network (Jessop, 2003; Sørensen, 2006; Sørensen \& Torfing, 2009). From this perspective, the meta-governor is also assumed to be able to steer or govern the other stakeholders, at least to some degree (Kickert et al., 1997; Rhodes, 1997, 2007). An assigned actor that cannot or would not regulate self-regulation is not acting as a meta-governor. The assumed benefits of metagovernance are based on recognizing the need to coordinate activities when aiming for an overarching goal, such as an efficient regional energy system. The metagoverning of networks is a complex affair, as partners in networks control vital information, contacts, and tangible resources, using them to determine the direction and content of their development activities.

In the regional climate and energy strategy work, the CABs have been assigned the role of meta-governors. How they form networks with stakeholders and how various participation strategies affect implementation efficiency will be discussed here.

\section{Stakeholder Participation in Strategic Planning}

Governance networks initiate collective action to achieve desired outcomes and as a way to avoid problems arising from collective action initiated by individual stakeholders (Healey, 6 
2007). From this perspective, stakeholder participation should be initiated as early as possible in a process. The meta-governor can adopt different approaches to participation in the process. In a deliberative participation approach, citizens take part in a consensus-seeking decisionmaking process, the participation taking the form of deliberation or dialogue (Bishop \& Davis, 2002; Hendriks, 2002; Henecke \& Khan, 2002; Levine et al., 2005; Hamilton \& WillsToker, 2006; Few et al., 2007; Ljung, 2010). Deliberation is a process of thoughtfully weighing options. Deliberation emphasizes the use of logic and reason as opposed to power struggle, creativity, or dialog (Habermas, 1998). Deliberative communication is a problemsolving form of communication that involves problem analysis, formulating evaluative criteria, and identifying and weighing alternative solutions. By making the deliberative process equitable and respectful a reasonable consensus is sought (Levine et al., 2005). The idea is to involve all participants, combining influence, inclusiveness, and deliberation, embracing democratic values such as citizens' rights to information, justice, and participation.

Deliberative participation has activist or grassroots origins, taking a bottom-up view of participation in which the goal is to redistribute the power over decisions from governments and officials to citizens. In its ideal form, deliberative participation should be initiated, owned, and controlled by citizens.

Collective learning is a collective process that creates relationships, insight and coordinated action through learning (Collins \& Ison, 2006; Schiller, 2009). In this type of process, learning occurs through collective engagement with others. During the process, actors learn about the roles, relationships, and rationales of the other stakeholders (Collins \& Ison, 2010; Ljung, 2010). Collins and Ison (2010) discuss this learning process as including: 
a) convergence of goals - understanding each other's goals, criteria, and knowledge, leading to more realistic mutual expectations and building relational capital b) process of co-creation - by gathering many perspectives a collective knowledge creation is developed that provides insight into the causes of and means required to change a situation

c) behavioral change and actions - resulting from understanding something through action ('knowing')

The aim of collective learning is to create relationships, understanding, behavioral change, and action. In collective learning, reaching consensus is not important (as it is in deliberative participation); instead, it is more interesting to discover, for example, why certain reasons are considered more legitimate and viable than others (Polk \& Knutsson, 2008). Various normative standpoints must be respected and all participants are perceived as having equal legitimate voices (Polk \& Knutsson, 2008; Cundill \& Fabricius, 2009).

Policy-driven participation is a strategy for expanding the range of voices (i.e. of those affected by a given decision) heard in the decision-making process. Policy-driven participation seeks to include those affected by a policy in the process. It also concerns the partial transfer of power from decision-makers to participants and creating a transparent process that exposes how decisions and policies are made (Rowe \& Frewer, 2000; Bishop \& Davis, 2002). Policy-driven participation takes an organizational approach; it applies the viewpoints of public officials and decision-makers, and can be described as mainly constituting a decision-support tool. The benefits of citizen participation include: decisions better aligned with public preferences, better policies and implementation, more legitimate decisions, and trust between the governed and the government (Irvin \& Stansbury, 2004). 
Politicians and public officials want to foster public involvement both to achieve greater acceptance for their decisions and to reach better decisions (Bayley \& French, 2008).

This analysis will consider whether the three participation strategies in which the CABs act as meta-governors (i.e. deliberative, collective learning, and policy participation) exert different influences on the outcome; for example, does deliberative participation result in more efficient implementation than does learning participation? Deliberative participation is characterized by the range of actors included in the process, the goals of which are open and negotiable. Collective learning participation is characterized by the priority of including a variety of actors possessing various kinds of knowledge. Policy participation is characterized by an emphasis on including stakeholders that will be vital for implementing measures and attaining goals.

\section{Materials and Methodology}

To analyze $\mathrm{CAB}$ practices in establishing strategic planning network initiatives using different participation approaches, and to identify their influence on the implementation phase, we focus on the CABs' climate and energy strategies. Our case material was collected in four selected counties in Sweden, i.e. Dalarna, Skåne, Västra Götaland, and Östergötland.

Various data collection techniques can be used in case study methodology (Yin, 2003). The present analysis is based on the strategy documents issued by the CABs and on qualitative interviews with regional and local stakeholders associated with the work on developing and managing the climate and energy strategies, see table 1. Eighty-six interviews were conducted between September 2008 and December 2009. Seven interviews were performed in person, 
while the remaining interviews were performed over the telephone. The interviews lasted between 15 minutes and one and a half hours. The questions asked in the interviews followed a semi-structured template. Semi-structured interviews allow for follow-up questions addressing any new themes that may emerge during the interview. The main questions concerned the development of the climate and energy strategies, the CABs, and the regional climate and energy work. All interviews were recorded and transcribed before the analysis.

Table 1. Actor categories and numbers of interviews divided between the four counties

\begin{tabular}{|c|c|c|c|c|c|c|}
\hline Actor & Description & Mandate & Dalarna & Skåne & $\begin{array}{c}\text { Västra } \\
\text { Götaland }\end{array}$ & $\begin{array}{l}\text { Öster- } \\
\text { götland }\end{array}$ \\
\hline $\begin{array}{l}\text { County } \\
\text { Administrative } \\
\text { Board (CAB) }\end{array}$ & $\begin{array}{l}\text { Governmental } \\
\text { controlled } \\
\text { regional } \\
\text { authority }\end{array}$ & $\begin{array}{l}\text { Mandated by the } \\
\text { government to } \\
\text { develop regional } \\
\text { climate and energy } \\
\text { strategies }\end{array}$ & 2 & 1 & 1 & 1 \\
\hline $\begin{array}{l}\text { Regional } \\
\text { Energy } \\
\text { Agency } \\
\text { (REA) }\end{array}$ & $\begin{array}{l}\text { Financed by } \\
\text { the Swedish } \\
\text { Energy } \\
\text { Agency, EU, } \\
\text { CAB, } \\
\text { Regional } \\
\text { Cooperation } \\
\text { Council }\end{array}$ & $\begin{array}{l}\text { Mandated to } \\
\text { promote energy } \\
\text { efficiency and the } \\
\text { use of renewable } \\
\text { energy sources }\end{array}$ & 1 & 2 & 1 & $\begin{array}{l}\text { Non- } \\
\text { existent }\end{array}$ \\
\hline
\end{tabular}




\begin{tabular}{|c|c|c|c|c|c|c|}
\hline $\begin{array}{l}\text { Regional } \\
\text { Cooperation } \\
\text { Council } \\
\text { (RCC) }\end{array}$ & $\begin{array}{l}\text { Regional } \\
\text { cooperation } \\
\text { between } \\
\text { municipalities } \\
\text { and a county; } \\
\text { politically } \\
\text { controlled }\end{array}$ & $\begin{array}{l}\text { Municipal interest } \\
\text { organization } \\
\text { mandated to support } \\
\text { municipalities and } \\
\text { facilitate } \\
\text { cooperation and } \\
\text { coordination } \\
\text { between them }\end{array}$ & 1 & 2 & 8 & 1 \\
\hline $\begin{array}{l}\text { Regional } \\
\text { Council } \\
\text { (RC) }\end{array}$ & $\begin{array}{l}\text { Politically } \\
\text { controlled } \\
\text { regional } \\
\text { organ }\end{array}$ & $\begin{array}{l}\text { Mandated to handle } \\
\text { regional } \\
\text { development }\end{array}$ & $\begin{array}{l}\text { Non- } \\
\text { existent }\end{array}$ & 4 & 2 & $\begin{array}{l}\text { Non- } \\
\text { existent }\end{array}$ \\
\hline $\begin{array}{l}\text { Municipal } \\
\text { officials } \\
\text { dealing with } \\
\text { environ- } \\
\text { mental and } \\
\text { energy issues }\end{array}$ & $\begin{array}{l}\text { Municipal } \\
\text { officials in } \\
\text { the areas of } \\
\text { energy, } \\
\text { climate, and } \\
\text { the } \\
\text { environment }\end{array}$ & $\begin{array}{l}\text { Control and } \\
\text { implement political } \\
\text { decisions; } \\
\text { disseminate } \\
\text { objective } \\
\text { knowledge of } \\
\text { environmentally } \\
\text { friendly energy } \\
\text { sources, energy } \\
\text { distribution, and } \\
\text { energy use }\end{array}$ & 5 & 7 & 9 & 6 \\
\hline Municipal & Elected local & & 5 & 6 & 12 & 9 \\
\hline
\end{tabular}




\begin{tabular}{|l|l|l|l|l|l|l|}
\hline politicians & politicians & & & & & \\
\hline Total & & & 14 & 22 & 33 & 17 \\
\hline
\end{tabular}




\section{Developing a Strategy and Forming a Network}

The CABs' mission was to serve as meta-governors and to take initiatives to develop climate and energy strategies in cooperation with county stakeholders. The counties face similar needs for restructuring their energy systems but had somewhat different features in terms of demography, history and geography. This will be discussed more thorough next.

\section{Introducing the counties}

The county of Dalarna is situated in central Sweden and consist of 15 municipalities and have 277000 inhabitants. Dalarna's feature is wood, $65 \%$ is woodland. Wood industry, steel industry and tourism are the three largest industries. Dalarna has a history of proactively dealing with climate and energy issues and is also seen as a national frontrunner in developing and working on climate and energy strategies.

The counties of Skåne in the south and Västra Götaland in the southwest are special cases in Sweden, having established strong Regional Councils (RCs) to undertake regional development at the behest of the CABs. The RCs exert great influence in their regions and have also initiated climate and energy strategies parallel to the CAB's strategy. Skåne covers a relatively small geographical area and consist of 33 municipalities and have in total 1,2 million inhabitants. Skåne has the highest average temperature in Sweden and is windy with great potentials for wind power. Skåne also has a considerable agriculture and food sector with favorable conditions for biogas production (Skåne CAB, 2007).

Västra Götaland consists of 49 municipalities and has a population of more than 1, 6 million inhabitants. A special feature for Västra Götaland County is that it uses a great amount of energy as all petrochemical industry in Sweden is located in the county, and a major share of 
other energy intensive industries, for example the vehicle industry. Transports and maritime shipping are also of great concern. The strategy also accentuates the industry and transports as the most important areas of concern for energy efficiency (Västra Götaland CAB, 2008).

The county of Östergötland in eastern Sweden, consist of 13 municipalities and is the fourth biggest county in Sweden with 420000 inhabitants. The county has over 1000 lakes. In north are woodlands, in the middle agricultural land and in east the archipelago. The county is a forerunner in waste combustion and the use of biofuels in combined heat and power plants. There is an established infrastructure for biogas used in public transportation and in private cars and ethanol is also produced in the county. The industry is quite diversified including $\mathrm{R} \& \mathrm{D}$, but there is also wood and metal industry.

\section{The contents of the strategies}

In 2008, climate and energy strategy documents were presented by all four CABs. These strategies, which share most of their content, declare themselves to be part of the CABs' work on the national environmental goals, municipal energy plans, and regional development programs. Even if the documents are called climate and energy strategies, the content concern mainly energy issues with energy efficiency and an increased use of renewables in energy production in focus. We will follow the empirical practice here and keep the label climate and energy strategies.

The municipalities in the counties are considered the most important regional strategy stakeholders, as the municipal land use plans are tools that can be used for coordinating regional climate and energy work. Visions for the climate and energy work are presented in all the strategies, along with proposals for arrangements and action plans. General areas of concern are energy systems and the use of energy for buildings, transport, production 14 
industry, and consumption. The strategies lack general specified goals and there are few proposals for hands-on initiatives. The Skåne climate and energy strategy is the only strategy mentioning substantial proposals for intervention, but even those proposals do not include set timetables or clarify the division of responsibility. The climate and energy strategy for Östergötland includes plans for the future with some proposals for intervention, and apportions responsibility for various issues to the region's municipalities and business community.

Besides the similar content of their written strategies, all the CABs formed various networks with various stakeholders in developing their strategies. These stakeholders included municipalities (which are especially important for implementation), the RCs and RCCs (as stakeholders with regional interests), industry (as also important for implementation), REAs (possessing extensive knowledge of energy issues), and public organizations.

Dalarna, often portrayed as a pioneer in regional energy work, had striven to coordinate regional actors to deal with various energy issues even before the government's 2008 budget document. It had developed a regional energy program in 2004-2005 (Dalarna CAB, 2005), and representatives of the region's municipalities, industries, and organizations had participated in various configurations in developing and implementing the program. The Dalarna CAB involved similar regional stakeholders in formulating the climate and energy strategy, which is also based on previous work and integrated visions and goals from the erlier energy program 2005. 
Skåne was one of four pilot counties ${ }^{1}$ that started to develop regional climate and energy strategies in 2007. Skåne had not previously worked on any coordinating issues concerning climate and energy. The initial work was performed by an in-house advisory group at the $\mathrm{CAB}$, using stakeholders from internal units to investigate existing opportunities for climate and energy policy and to develop a project plan. The groundwork was done in close cooperation with representatives of the Skåne Energy Agency and other actors (e.g. the RC, Chalmers University, other CABs, and national governmental authorities). Former collaborations and previously established networks were used to identify stakeholders who would be suitable participants. These networks consisted of national boards and authorities, interest groups, and municipal civil servants. Dialogue with these actors was informal and based mostly on previously established informal relationships. Gathering a range of energy expertise to participate in the process seemed to be an unspoken goal. A proposed strategy was presented in 2007 and submitted for comment to the municipalities, organizations, interest groups, and business corporations in Skåne. Workshops were held in which regional and municipal actors could discuss the proposed strategy.

The Västra Götaland CAB started to develop a climate and energy strategy in 2008 when the national budget document was presented. The CAB had previously dealt with climate and energy issues, but in a process led by the Västra Götaland RC. In 2005-2006, the RC had presented Smart Energy, a regional sustainable development program and strategy for ending fossil fuel dependence, and started a process of dialogue on energy use with a variety of actors in the region. This dialogue involved the $\mathrm{CAB}$, as the $\mathrm{CAB}$ was working on the national

\footnotetext{
${ }^{1}$ The 2007 letter of recommendation gave assignments to develop climate and energy strategies to the CABs of Skåne, Kalmar, Stockholm, and Norrbotten.
} 
environmental goals and had close connections with governmental authorities. The CAB's Climate and Energy Strategy for Västra Götaland (2008) represents a continuation of its earlier work with the RC. The strategy aims to be a starting point for climate and energy efforts and to create viable dialogue between national and regional authorities and the municipalities on how to reduce energy use in industry and the community.

The Östergötland CAB started its climate and energy strategy work when the 2008 governmental budget document was released; it had not previously worked specifically on strategic climate and energy issues. The Östergötland CAB formed a special advisory group including many external stakeholders, such as the RCC, municipalities, the REA, and the CC, which met several times. A workshop held in April 2008 involved about 50 special advisers from municipalities, regional and national authorities, various institutions, and energy companies. In addition, a reference group was working with stakeholders from regional agencies, municipalities, the CC, industry, universities, and non-profit organizations. The working period was short but intense. The Climate and Energy Strategy for Östergötland (2008) included a preliminary goal of fostering broad collaboration in the region and of reaching consensus decisions, with the $\mathrm{CAB}$ serving as coordinator. The advisory group was given an important role in the ongoing work that was to proceed in groups or forums, including public and private stakeholders that would work together on the specific themes or issues of the strategy. These stakeholders included the RCC, municipalities, the County Council, and universities.

In sum, the CABs formed networks at different stages of the strategy processes; these networks including contacts established during earlier work as well as stakeholders connected with specific issues of interest. In establishing networks and developing strategies, the CABs 17 
applied various partly similar approaches to stakeholder participation, with associated effects on strategy implementation. This will be further examined in terms of the network participation strategies deliberative participation, collective learning, and policy-driven participation, including discussions of various aspects and problems concerning stakeholder participation in regional climate and energy strategic work.

\section{The Deliberative Participation Approach}

A deliberative participation approach emphasizes consensus-seeking dialogue, weighing various options and involving many active stakeholders, including citizens. None of the CABs invited citizens to participate in formulating and then implementing the strategies, though all CABs formed networks involving many stakeholders. The Skåne CAB wanted to forge a cocreative process and pursue legitimacy, but failed to involve affected participants on equal terms and did not give all stakeholders equal voice in the process. Many actors were also involved in the Dalarna development process, but these actors were mainly stakeholders affected by the strategy. The Dalarna $\mathrm{CAB}$ coordinated activities and acted as a steering agent of the strategy network. We will leave these two CABs for now and focus on the processes in Östergötland and Västra Götaland.

The Östergötland CAB formed a network comprising many external stakeholders with different mandates in the county for developing climate and energy strategy. The strategy did not result in any concrete goals and the Östergötland climate and energy strategy is also far from being realized. The $\mathrm{CAB}$ acted as a meta-governor in gathering actors from many levels in the county; it guided these actors in the development process by means of workshops and working groups, and made these actors responsible for the climate and energy work. The Östergötland $\mathrm{CAB}$, however, did not act as a meta-governor when it came to realizing the 18 
strategy goals. It had few opportunities to continue active work in the networks during the strategy implementation process, and key actors were unaware of the leading roles conferred on them or that they were responsible for certain areas. In addition, municipal stakeholders criticized the CABs, saying that problems could arise when the open-ended goals were to be realized, due to contradictory municipal and regional values. A municipal politician in Östergötland had a solution to the problem of the government and regional levels trying to dictate what the municipalities should do:

It would be easier if we had another organization in which the municipalities could come together and establish a regional council to work on these issues.

The Västra Götaland climate and energy strategy was based on work conducted by the RC in which it had already formed a broad network. The strategy document, however, was developed mostly by internal actors at the $\mathrm{CAB}$, which was not acting as a meta-governor of the formation process. The RC was instead an actor with authority equivalent to that of the $\mathrm{CAB}$ in Västra Götaland, taking the lead in regional climate and strategic energy issues.

The next step for the Västra Götaland CAB was the participation phase, including discussion of what actors to include in the network; strategy implementation was not yet an issue. For future work, Västra Götaland CAB expressed a preference for a deliberative participation approach. The goal was, through active dialogue, to jointly solve climate and energy problems, making it crucial to have active networks participating in the strategy work. The CAB's internal energy group was to discuss common goals and organizational issues pertaining to climate and energy in cooperation with the RC, RCC, and industrial actors, while the RC would seek to involve municipalities, industry, and citizens in the climate and 19 
energy work. The CAB gave itself the responsibility to inform, coordinate, offer support, supervise, and handle permissions. Some municipal representatives in Västra Götaland, however, criticized the $\mathrm{CAB}$ for not entering into active dialogue with them from the beginning of the development process. The Västra Götaland CAB admitted that coordinating many stakeholders in viable dialogue was a challenge, and it fumbled in determining what exactly these stakeholders should do in the climate and energy area in the region. Some municipalities in the region, however, wanted the $\mathrm{CAB}$ to clarify its position in the region regarding climate and strategic energy issues and to become more active. A municipal politician in Västra Götaland stated that it was problematic that the CAB did not involve the municipalities in the planning process:

If they want the municipalities to act and feel involved, then all municipalities must be part of this from the beginning ... Anything that simply comes from above and falls on our desks in the municipality ... we don't care about that in the same way.

A significant pattern in all four counties was for municipal stakeholders to maintain that it is crucial that the CABs involve the municipalities and gain their approval of the climate and energy strategies if actual measures are to be implemented. Municipal representatives were aware that they were the only actors able to implement the strategies in real projects, and that the CABs could employ only soft management control measures, such as discussions and information provision. That gives the municipalities the right to decide what to implement, and neither the $\mathrm{CABs}$ nor the RCs and RCCs can force the municipalities to implement measures affecting their monopoly on planning. 
Some municipal stakeholders considered the CABs of Västra Götaland, Östergötland, and Skåne not responsible for taking action on regional climate and energy issues or for influencing the regional energy system.

Stakeholders in Östergötland and Dalarna believed that forming a regional council could facilitate implementation in the region. However, municipal actors in Skåne and Västra Götaland, which had established RCs, did not consider regional councils the entire solution. An RC does not necessarily make regional decisions that suit all municipalities, according to municipal stakeholders, and an RC cannot make decisions forcing the municipalities to act.

\section{Collective Learning Participation Approach}

Collective learning is a participation approach emphasizing the inclusion of a variety of stakeholders; in this approach, learning occurs in the relationships and in coordinating action in order to facilitate social change. The strategy work of the Skåne CAB was partly characterized by a collective learning approach in which stakeholders possessing various kinds of knowledge were involved in creating new relationships and in working together to achieve change in the region. The Skåne $\mathrm{CAB}$ complained that they had been granted little time to develop the strategy, which reduced the chances of developing a deliberative participation process. This meant that participants were drawn from a narrow selection of mostly previously established contacts and that little time was available for open discussion and learning.

The Skåne CAB was also seeking ways to handle discussions of strategic climate and energy issues in the county. It said that time would be needed to find appropriate working methods, 
and that coordinating active dialogues with county stakeholders posed a challenge. In addition, no financial resources were granted to support the strategy assignment.

In Skåne, the RC had authority equivalent to that of the CAB. The presence of two major actors can lead to conflict in networks when these actors have equivalent power and resources, possibly reducing the advantages of working in networks (Kickert et al., 2007). The $\mathrm{RC}$ was also identified as a competing meta-governor in regional climate and energy issues. Many municipalities in Skåne supported the CAB as the meta-governor in the region and thought it should have acted more as a governor in developing the strategy, i.e. should have provided clear directions. These municipal stakeholders found the strategy too forward looking, vague, and unhelpful in guiding the municipalities in their daily work.

Implementation of the climate and energy strategy in Skåne was starting and the Skåne CAB was trying to foster legitimate collaboration with the RC and the Skåne Energy Agency. The Skåne CAB did not assume the role of meta-governor in the implementation stage. However, together with the other participants, it had engaged in an equitable collective learning process to devise a regional platform of relationships to address climate and energy issues in Skåne. Representatives of municipalities with different competences would be important participants in this effort, according to the Skåne CAB.

\section{Policy-driven Participation}

Including only concerned stakeholders and fostering transparency in the decision-making process are essential to the policy-driven participation approach. This was especially the case in the Dalarna CAB strategy. The Skåne, Västra Götaland, and Östergötland CABs tried but had a difficult time developing policy participation strategies. Some actors in these counties 22 
were unaware that they had been invited to participate in the strategy work. Although the Östergötland $\mathrm{CAB}$ tried to include actors affected by related policies in the strategy process, implementation was not successful. Broad stakeholder participation was more important for the process itself than for achieving the energy and climate goals. Västra Götaland lacked knowledge of the relevant stakeholders and existing knowledge in the region to include in a participation process. The Skåne $\mathrm{CAB}$, however, was more active in forming a strategy development network than was the Västra Götaland CAB, and involved the municipalities in developing the strategy. However, this occurred only after the draft climate and energy strategy was presented.

In the process of developing the strategy, the Dalarna CAB, on the other hand, formed a network and included stakeholders that would be affected by the climate and energy policy. This broad network supported the development of the climate and energy strategy, giving the participants insight into the process. The Dalarna CAB established a 'legitimation process' in which actors could participate by creating a steering committee that included the county governor, RCC president, and key sector representatives. Involving regional actors in the committee was a way to create legitimacy, commitment, and opportunities for cooperation. The $\mathrm{CAB}$ representatives highlighted cooperation with concerned stakeholders as important in the strategy work; this comment from the beginning of an interview was typical:

It should be a regional strategy, not the CAB's strategy, and it should involve the whole region and cooperation with other stakeholders is necessary.

The work by the Dalarna CAB partly differed from that of the other CABs. Regional actors in Dalarna could easily cite concrete examples of the content and aims of the Dalarna climate 23 
and energy strategy. In all counties, the strategies were generally known to most local and regional actors, with Västra Götaland as an exception, but few stakeholders, except in Dalarna, knew the content of the strategies. The Dalarna CAB differed from the Västra Götaland and Skåne CABs in that it did not have to deal with a competing regional actor. The Dalarna CAB, with its strongly established climate and energy networks in the county, had the opportunity to continue its work as meta-governor in the strategy implementation phase, which had already started. Municipal actors also considered the Dalarna CAB a metagovernor accountable for the climate and energy work in the county. In Dalarna, participants particularly remembered working with the Dalarna $\mathrm{CAB}$, for example, when developing a template text for the municipal energy plan or holding a seminar on a specific issue.

\section{Discussion}

The processes of developing climate and energy strategies were designed in different ways in the studied counties, and included various kinds of collaboration with regional stakeholders from industry, NGOs, municipalities, and citizens' associations. In this sense, the CABs took the lead in deciding what actors could join the network. Although the CABs generally took the lead in encouraging participation in the development process, few CABs acted as metagovernors when it came to actively coordinating the networks to achieve the implementation of legitimate goals. Different participation strategies for establishing networks have different purposes and resulted in different implementation conditions.

The Dalarna CAB has employed a combination of deliberative and policy participation and acted as meta-governor of the strategy process. Its history of taking the lead on energy issues in the region gave it the advantage of possessing energy and climate knowledge tailored to the region. This $\mathrm{CAB}$ was familiar with relevant regional stakeholders affected by energy and 24 
climate policy, and these actors were accustomed to the $\mathrm{CAB}$ as a powerful regional actor. The relationship between the $\mathrm{CAB}$ and the affected stakeholders was transparent and based on trust. When the CAB was commissioned to develop an energy and climate strategy, it could take a policy participation approach and, from the beginning, focus on how to ensure that the strategy was accepted and implemented by stakeholders in the county. Implementation is likely to succeed in the future, as acceptance of the climate and energy strategy is supported by municipal energy plans rooted in historical regional collaboration.

The Skåne CAB mostly endeavored to include a variety of actors with various types of knowledge in its participation process for the strategy. It acted partly as a meta-governor in initiating the strategy, but failed later in this. The $\mathrm{CAB}$ did not assume the coordinating role in establishing networks that included other competing regional actors perceived as having equal and legitimate voices when it came to climate and energy planning, even though stakeholders in Skåne asked for policy participation and for the CAB to act as meta-governor. The work of the Skåne CAB was instead closer to collective learning in how the strategy was developed and how relationships were created in order to gain legitimacy. This gave rise to a regional collective platform with other regional actors, which allowed the collective learning strategy to foster further work and discussion, but did not necessarily result in strategy implementation at a local level.

The Östergötland CAB tried, but failed, to establish a policy participation process, and stakeholders were unaware that they had been assigned responsibility for various issues. The strategy process in Östergötland was instead characterized by a deliberative participation approach that included participants in viable dialogues and attempted to include the stakeholders in a decision-making process. Involving many actors in the process, as was done 25 
in Östergötland, is no guarantee of strategy implementation, which in this case had few opportunities to succeed because the stakeholders did not understand their assignments.

The Västra Götaland CAB was planning to initiate some sort of deliberation process, although it lagged Östergötland in doing so and the strategy was not developed from the beginning, in line with a deliberative approach. The Västra Götaland CAB was only beginning to gather knowledge, map relevant energy activities in the region, and identify stakeholders with which to establish relationships. It had started to contact a broad number of actors in the region, but it is unclear how that effort influenced future strategy formulation. This has resulted in an energy and climate strategy that is not yet at the implementation stage. The Västra Götaland $\mathrm{CAB}$ also lacks an active network, and the discussion of metagovernance is not relevant in its case.

Table 2. Network participation strategies used

\begin{tabular}{|l|l|l|}
\hline & \multicolumn{1}{|c|}{ Meta-governor } & Non meta-governor \\
\hline Deliberative & & Västra Götaland \\
participation & & Östergötland \\
\hline Collective & & Skåne \\
\hline learning & & \\
Policy & Dalarna & \\
\hline
\end{tabular}




\section{Conclusions}

CABs in Sweden have long worked on disseminating and translating national environmental goals to the county level, but they had not previously been clearly tasked with leading and coordinating regional and local actors in collaborating on energy issues. Metagovernance theories emphasize that management can, by using various incentives and participation approaches; encourage collaboration and resource allocation between actors who would not otherwise meet and work together. Being meta-governors and forming networks linking stakeholders to participate in developing regional climate and energy strategies for the regions were difficult tasks for the CABs. A history of establishing regional networks and competition between meta-governors were factors affecting CABs ability to assume the meta-governor role, giving the $\mathrm{CABs}$ different preconditions for the assignment. Whether or not a $\mathrm{CAB}$ acted as meta-governor affected how it could use stakeholder participation. In establishing networks, stakeholder participation took different forms depending on whether or not the $\mathrm{CAB}$ acted as meta-governor. The developed strategies are all similar in content. The particular stakeholder participation approach used, or whether or not the $\mathrm{CAB}$ was acting as meta-governor in the strategy development process, did not affect the strategy content.

Different participation approaches, however, have different implications for the acceptance and implementation of the climate and energy strategies, and for whether they become vital documents to stakeholders in the counties. The policy participation approach in which the $\mathrm{CAB}$ acted as meta-governor leading the process gained acceptance, giving the strategy potential to be implemented in the county by affected stakeholders. In acting as metagovernor, the $\mathrm{CAB}$ was given responsibility for the process. Participation approaches involving many stakeholders, but in which the $\mathrm{CAB}$ acted only partly or not at all as meta- 
governor, were not fully considered accountable by stakeholders in the development stage and not at all accountable in the implementation stage. These strategies are less likely to be known and accepted by affected stakeholders and less likely to shape implementation. That makes legitimizing the strategy and the CAB's coordinator role important for the process. CABs unable to assume the meta-governor role in their region are very unlikely to gather affected local and regional authorities to participate in networks for the strategy work. $\mathrm{CAB}$ failure to fulfill the meta-governor role and to take a policy participation approach on a regional level in putting national goals into practice can limit future improvement of regional coordination in the interest of energy efficiency and environmental sustainability. 


\section{References}

Aall, C., Groven, K., \& Lindseth, G. (2007). The scope of action for local climate policy: the case of Norway. Global Environmental Politics 7(2) pp. 83-10.

Albrechts, L. (2004). Strategic (spatial) planning reexamined. Environment and Planning B: Planning and Design, 31, pp. 743-758.

Baker, S., \& Eckerberg, K. (2007). Governance for sustainable development in Sweden: the experience of the local investment programme. Local Environment, 12(4), pp. 325-342.

Bayley, C., \& French, S. (2008). Designing a participatory process for stakeholder involvement in a societal decision. Group Decision and Negotiation, 17(3), pp. 195-210.

Betsill, M.M., \& Bulkeley, H. (2007). Looking back and thinking ahead: a decade of cities and climate change research. Local Environment, 12(5), pp. 447-456.

Bishop, P., \& Davis, G. (2002). Mapping public participation in policy choices. Australian Journal of Public Administration, 61(1), pp. 14-29.

Buono, F., Pediaditi, K., \& Carsjens, G.J. (2012). Local Community Participation in Italian National Parks Management: Theory versus Practice. Journal of Environmental Policy \& Planning, 14:2, pp. 189-208. 
Burch, S. (2010). In pursuit of resilient, low carbon communities: an examination of barriers to action in three Canadian cities. Energy Policy, 38(12), pp. 7575-7585.

Collins, K., \& Ison, R. (2010). Trusting emergence: some experiences of learning about integrated catchment science with the environment agency of England and Wales. Water Resources Management, 24(4), pp. 669-688.

Cundill, G., Fabricius, C. (2009). Monitoring in adaptive co-management: toward a learning based approach. Journal of Environmental Management, 90(11), pp. 3205-3211.

Dalarna CAB. (2005). EnergiIntelligent Dalarna - Program for regional energy collaboration. Retrieved from The County Administration Board in Dalarna, Falun, Sweden.

Dalarna CAB. (2008). Climate and Energy Strategy for Dalarna. Retrieved from The County Administration Board in Dalarna, Falun, Sweden.

Few, R., Brown, K., \& Tompkins, E. (2007). Public participation and climate change adaptation: avoiding the illusion of inclusion. Climate Policy, 7, pp. 46-59.

Hendriks, C. (2002). Institutions of deliberative democratic processes and interest groups: roles, tensions and incentives. Australian Journal of Public Administration, 61(1), pp. 64-75.

Henecke, B., \& Khan, J. (2002). Medborgardeltagande i den fysiska planeringen - en demokratiteoretisk analys av lagstiftning, retorik och praktik [Citizen participation in physical 30 
planning - a theoretical analysis of legislature, rhetoric and praxis from a democracy perspective], Working Paper, Department of Sociology, Lund University, Sweden.

Habermas, J.(1998). On the Pragmatics of Communication. Cambridge: MIT Press.

Hamilton,. J, \& Wills-Toker, C. (2006). Reconceptualizing dialogue in environmental public participation. The Policy Studies Journal, 34(4), pp. 755-775.

Healey, P. (2009). The pragmatic tradition in planning thought. Journal of Planning Education and Research, 28(3), pp. 277-292.

Irvin, R. A., \& Stansbury, J. (2004). Citizen participation in decision making: is it worth the effort?. Public Administration Review, 64(1), pp. 55-65.

Jessop, B. (2003). Governance and metagovernance: on reflexivity, requisite variety, and requisite irony. In Bang, H. P. (Ed.), Governance, as Social and Political Communication, pp. 142- 172. Manchester: Manchester University Press.

Kickert, W. J. M., Klijn, E-H., \& Koopenjan, J. F. M. (1997). Managing Complex Networks: Strategies for the Public Sector. London: Sage Publications.

Kowalski, K., Stagl, S., Madlener, R., \& Omann, I. (2009) Sustainable energy futures: methodological challenges in combining scenarios and participatory multi-criteria analysis. European Journal of Operational Research, 197(3), pp. 1063-1074. 
Levine, P., Fung. A., \& Gastil, J. (2005). Future directions for public deliberation. Journal of Public Deliberation, 1(1), Article 3.

Ljung, S. (2010). Approaches to Participative Planning: Potential Applications in Municipal Energy Planning (Master's thesis). Department of Thematic Studies: Water and Environmental Studies, Linköping University, Linköping.

Magnusson, D. (2011). Between municipal and regional planning: the development of regional district heating systems in Stockholm from 1978 to 2010. Local Environment, 16(4), pp. 319-337.

Monno, V., \& Khakee, A. (2012). Tokenism or Political Activism? Some Reflections on Participatory Planning. International Planning Studies, 17(1), pp. 85-101.

Narodoslawsky, M., \& Stoeglehner, G. (2010). Planning for Local and Regional Energy Strategies with the Ecological Footprint. Journal of Environmental Policy \& Planning, 12(4), pp. 363-379.

Palm, J. (2006) Development of sustainable energy systems in Swedish municipalities: a matter of path dependency and power relations. Local Environment, 11(4), pp. 445-457.

Palm, J. (2011). Regional climate and energy strategies: actors, responsibilities, and roles. Paper presented at the World Renewable Energy Congress, Linköping, Sweden. 
Pierre, J. (2000). Debating Governance: Authority, Steering and Democracy. Oxford: Oxford University Press.

Polk, M., \& Knutsson, P. (2008). Participation, value rationality and mutual learning in transdisciplinary knowledge production for sustainable development. Environmental Education Research, 14(6), pp. 643-653.

Rhodes, R.A.W. (1997). Understanding Governance: Policy Networks, Governance, Reflexivity and Accountability. Buckingham: Open University Press.

Rhodes, R.A.W. (2007). Understanding governance: ten years on. Organization Studies, 28(8), pp. 1243-1264.

Rowe, G., \& Frewer, L. J. (2000). Public participation methods: a framework for evaluation. Science, Technology \& Human Values, 25(3), pp. 3-29.

Sabatier, P.A., \& Jenkins-Smith, H. C. (1993) Policy Change and Learning: An advocacy Coalition Approach. Boulder: Westview Press.

Schiller, F. (2009) Linking material and energy flow analyses and social theory. Ecological Economics, 68(6), pp. 1676-1686.

SOU 2007:13 (Swedish Government Official Reports), Regional utveckling och regional samhällsorganisation 
SFS 1977:439. Lag Om Kommunal Energiplanering.

Skåne CAB. (2008). Climate and energy strategy for Skåne. Retrieved from The County Administration Board in Skåne, Malmö, Sweden.

Swedish Government. (2008). Governmental Budget Bill 2008/09:1.

Sørensen, E. (2006). Metagovernance: the changing role of politicians in processes of democratic governance. The American Review of Public Administration, 36(1), pp. 98-114.

Sørensen, E., \& Torfing, J. (2009). Making governance networks effective and democratic throught metagovernance. Public Administration, 87(2), pp. 234-258.

Tonn, B., English, M. \& Travis, C. (2000). A framework for understanding and improving environmental decision making. Journal of Environmental Planning \& Management, 43(2), pp. $163-183$.

Westholm, E., Amcoff, J., Falkerby, J., Gossas, M., \& Stenlås, N. (2008). Regionen som vision - det politiska projektet Stockholm -Mälarregionen. Stockholm: SNS Förlag.

Yin, K. (2003). Case study research: designs and methods. Thousand Oaks: Sage publications.

Västra Götaland CAB. (2008). Climate and Energy Strategy for Västra Götaland. The County Administration Board in Västra Götaland, Göteborg. 
Östergötland CAB. (2008) Climate and Energy Strategy for Västra Götaland. Retrieved from The County Administration Board in Östergötland, Linköping. 